\title{
Alternative interpretations of grain-size data from Quaternary deposits
}

\author{
Elżbieta Mycielska-Dowgiałło ${ }^{1, *}$ \& Małgorzata Ludwikowska-Kędzia² \\ ${ }^{1}$ The Family Alliance School of Higher Education, M. Grzegorzewskiej 10, 02-778, Warsaw, Poland; \\ e-mail: mycdow@wp.pl \\ ${ }^{2}$ Institute of Geography, Jan Kochanowski University in Kielce, Świętokrzyska 15, 25-418, Kielce, Poland; \\ e-mail: mlud@ujk.kielce.pl \\ ${ }^{*}$ corresponding author
}

\begin{abstract}
Several possibilities to present and to interpret the results of granulometric analyses of Quaternary fluvial, aeolian, glacial and wash-out slope deposits were investigated. Attention is paid particularly to the cumulative curves at a probability scale and the frequency curves, and it is shown how these curves can help to determine the sedimentary environment. The inclination of the cumulative curves in the part of the maximum proportion of a particular grain size appears significant. It appears possible to obtain information on the density and dynamics of the transporting medium from the course of the cumulative curves (inclination and spread of grain size).

The examination of textural parameters allows to draw regression lines characteristic of both deposits from various sedimentary environments and deposits from one single environment but with different histories as to their transport dynamics.
\end{abstract}

Keywords: Quaternary deposits, grain-size distribution, cumulative curves, frequency curves, textural parameters

\section{Introduction}

Analysis of the grain-size distribution of gravel, sand and silt fractions often provides a basis for the study of other textural features of deposits. The various, sometimes controversial, interpretations of such data have led to numerous discussions (see Friedman \& Sanders, 1978; Mycielska-Dowgiałło, 2007; Flemming 2007; Hartmann \& Flemming, 2007; Szmańda, 2007; Weltje \& Prins, 2007). It becomes more and more clear that the grain type and size do not depend on the transport processes and the sedimentation conditions; transport-related features are better expressed in the structural features (Fleming, 2007; Hartmann \& Flemming, 2007).
Interpretation of the transport mechanism on the basis of structural features is certainly justified when outcrops are studied, but can hardly be applied in the case of drillings.

Recent investigations of thousands of samples from sediments deposited in all kinds of environments in Poland and abroad, from both outcrops and drillings, now offer a framework for interpretations that previously were possible exclusively by granulometric analyses (Mycielska-Dowgiałło, 2007; Racinowski et al., 2001). This refers mainly to the interpretation of depositional environments but can, in our opinion, also be applied for the interpretation of the energy and nature of the transporting medium. 
The aim of the present contribution is to present alternative possibilities for the interpretation of the grain-size distribution of Quaternary deposits in some sedimentary environments, based on examination of:

(1) cumulative curves on a probability scale with particular regard to their inclination and spread of the grain-size;

(2) comparison of the cumulative and frequency curves;

(3) comparison of the frequency curves found for sediments in some environments and in the parent material;

(4) relationships between the granulometric indices of Folk \& Ward (1957): mean grain diameter $(\mathrm{Mz})$, standard deviation $\left(\sigma_{\mathrm{I}}\right)$ and skewness $\left(\mathrm{Sk}_{\mathrm{I}}\right)$, and particularly the course of the regression line in the relationship between $\mathrm{Mz}$ and $\sigma_{\mathrm{I}}$ (the relationships between $S k_{\mathrm{I}}$ and $\mathrm{Mz}$, and between $\mathrm{Sk}_{\mathrm{I}}$ and $\sigma_{\mathrm{I}}$ are particularly useful for deposits in a homogeneous sedimentary environment, where the position of a cluster of points enables to distinguish a specific facies);

(5) the Passega C-M diagram.

The interpretative possibilities of the results of granulometric analyses can be tremendously enhanced if the analysis of the grain-size distribution of the transported sediments (Flemming, 1988) is accompanied by studies of other textural features (Friedman et al., 1992) such as (1) the rounding and the mat ratio of the quartz grains in the sandy fractions (Mycielska-Dowgiałło, 1992, 1993, 2001; Izmaiłow, 2001; Mycielska-Dowgiałło \& Woronko 2004); (2) Scanning Electronic Microscope (SEM) analysis of the surface micromorphology of the sand- and silt-sized quartz grains (Mycielska-Dowgiałło, 1988; Mycielska-Dowgiałło et al., 1995, 2007); and (3) analysis of the mineral and petrographical composition of the deposit (Cichosz-Kostecka et al., 1991; Elsner, 1992; Mycielska-Dow giałło, 2001, 2007). The interpretative possibilities also increase if the analysis covers not only the deposits under study but also the deposits which constitute their potential source material (Folk, 1971; Flemming, 1988; MycielskaDowgiałło, 2007).

\section{Presentation of the grain-size distribution as cumulative and frequency curves}

Grain-size distributions can be visualized through diagrams. The types most applied are cumulative curves and frequency curves.

Most frequently, the results of granulometric analyses are presented in the form of cumulative curves on a $t$ probability scale (on the vertical axis) vs. $\Phi$ (phi) units (on the horizontal axis), and in the form of frequency curves, with frequency units on the vertical axis and $\Phi$ units (together with their corresponding values in millimetres) on the horizontal axis. Frequency units are calculated as follows: the proportion of grains of a particular size interval (expressed as a weight percentage) divided by $\Delta \Phi$ within the same interval. They thus are a measure of the sorting of the deposit. For interpretation purposes, it is useful to show the grain-size characteristics using both methods (Mycielska-Dowgiałło, 2007).

\subsection{Cumulative curves}

The basic value of presenting the grain-size distribution as cumulative curves on a probability scale consists in the opportunity to evaluate them within the range of their straight sections, illustrating grain-size groups of normal or similar distribution. This method was used by Visher (1969), who distinguished three basic curve segments, indicating different ways of sediment transport (through saltation: segment A; in suspension: segment B; and bed load: segment C). Since Visher's work, investigations of grain-size distribution have significantly expanded to include deposits of various sedimentary environments and facies. Apart from fragments of cumulative curves corresponding to a normal distribution (most often limited to the sand fraction), admixtures of coarser and finer grains occur, which do not form normal distributions (Tanner, 1964). Nevertheless, their presence or absence is important for the interpretation of the sedimentary environment. 


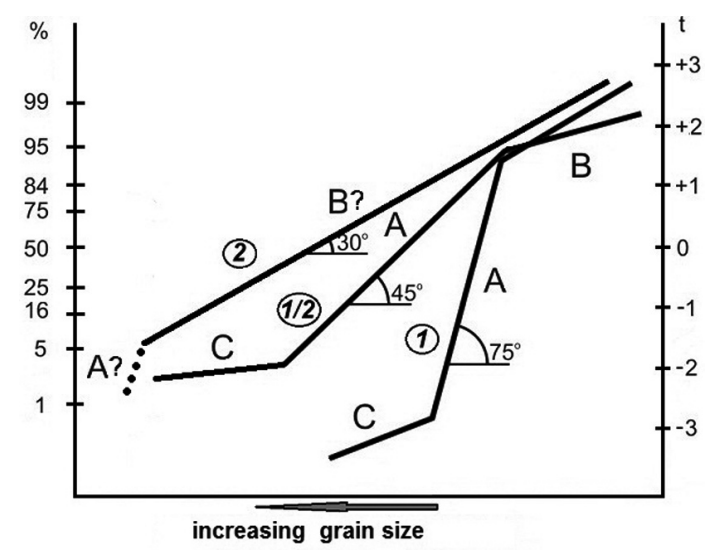

Fig. 1. The three basic groups of cumulative curves for sediments deposited by currents. They appear on a probability scale as segments $(\mathrm{A}, \mathrm{B}, \mathrm{C})$ with different inclination and as a transitional group (1/2) (modified after Mycielska-Dowgiałło, 2007).

Investigations conducted in Poland of deposits of various origins (Mycielska-Dowgiałło, 2007) have enabled to distinguish three groups of grain-distribution curves (Fig. 1). This may be done if the ' $t$ ' units on the probability scale correspond in their geometrical dimension to those on the $\Phi$ scale (Fig. 2A). The basic criteria for distinguishing these groups are the course of the cumulative curves for the prevailing fractions of the deposit $(>60 \%)$ and the sorting of these fractions, as marked by the section's inclination. Most commonly segment $\mathrm{A}$ is the best sorted (most inclined section), containing the sand fraction. According to Visher (1969), such a sediment has been transported through saltation.

\subsubsection{The first group of cumulative curves}

The first group (Fig. 1, graph 1) comprises curves that demonstrate a well-sorted population, with $>60 \%$ of total sample mass, and is characterised by a steeply inclined section A within the $85^{\circ}-45^{\circ}$ (mostly within $60^{\circ}-70^{\circ}$, towards the $x$-axis) interval. Admixtures of coarser and finer grains occur within this group as well (segments B and C). Simultaneously in this group appear often monosegmental cumulative curves (Fig. 2; Fig. 3A $b$ ) The first group of the cumulative curves is most often characteristic of aeolian deposits (Fig. 2), but occasionally is found for beach and fluvial deposits (particularly in meandering rivers) (Fig. 3A $b$ ).

The less steep inclination of the cumulative curves for coversand (approx. 50 $0^{\circ}$ (Fig. 2A) as compared to dune deposits (approx. 70) (Fig. 2B, C) points to shorter aeolian transport for the coversand than for the dune deposits.

\subsubsection{The second group of cumulative curves}

The second group of cumulative curves (Fig. 1 , graph 2, continuous line) comprises curves in which the major section $(>60 \%$ of the total sample mass) represents poorly sorted material. The inclination of segment (B?) is concentrated around the value of $30^{\circ}$ (most often $20^{\circ}-$
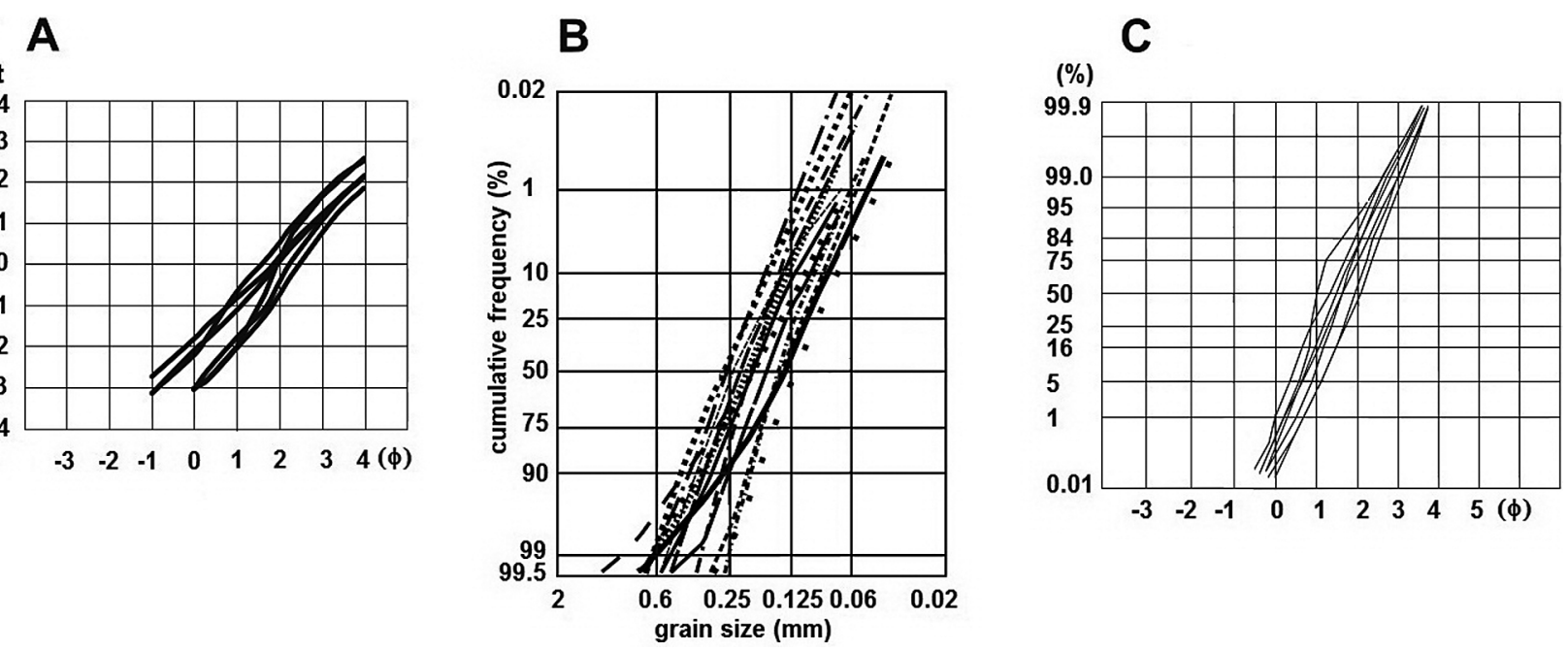

Fig. 2. Cumulative curves.

A: Coversands (Dąbski, Woronko \& Szwarczewski, unpublished data); B: Dune deposits of cold-climate zones (modified after Seppälä, 2004); C: Dune deposits (data after Zieliński, 2009). 

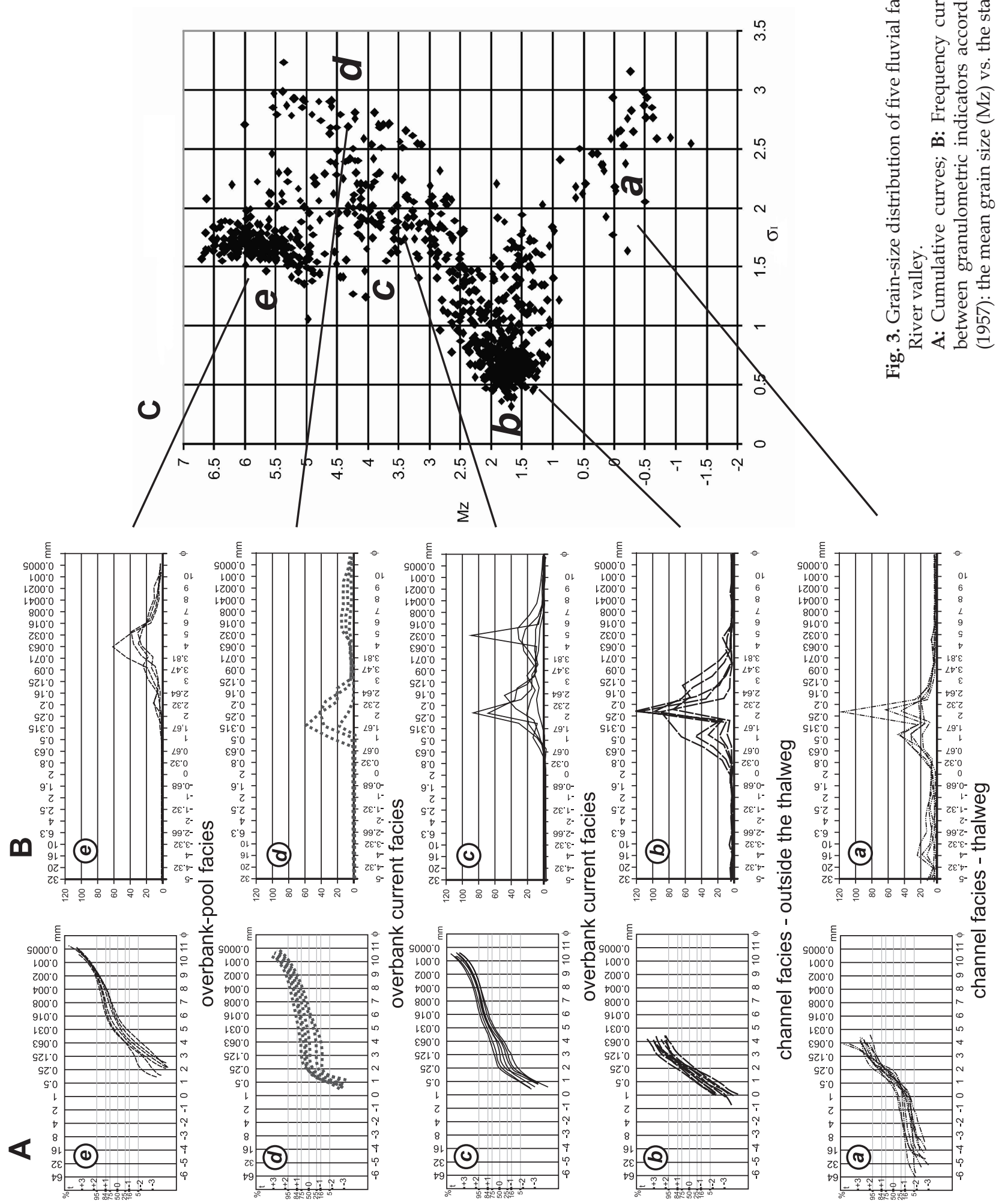
$\left.40^{\circ}\right)$. These curves concern the fractions from silt to coarse gravel. This type of cumulative curve is characteristic of deposits derived from high-energy currents. While settling, cobbleand pebble-sized particles are deposited first, then the finer grains are trapped between them (Garde, 1972). They are characteristic of fluvioglacial deposits (particularly subglacial ones), as well as of braided-river deposits. This group of curves can occasionally include sediments of meandering rivers (Fig. 3) and surficial run-off sediments. These curves, although resembling each other as to their course, represent different grain-size spectra (Fig. 4A, B). This second group of cumulative curves is characteristic also of sediments transported in the medium of considerable density (Fig. 5).
Occasionally, cumulative curves in the second group may have two segments (Fig. 1: continuous and dotted lines). In these cases, the less inclined section is limited from below by a very steep section. The portion of the deposit indicated by the steep section of the curve points to the largest grain size. Its content in the total deposit varies significantly and ranges from several percent in subglacial and fluvial deposits to several dozens of percents in sand/ silt/clay mixtures (Ludwikowska-Kędzia, 2000; Szmańda, 2002). This steep segment probably defines the upper competence limit of a given sediment transporting medium.

The course of the second curve group (Fig. 1, graph 2) does not fall under Visher's classification system. In the case of a slightly inclined
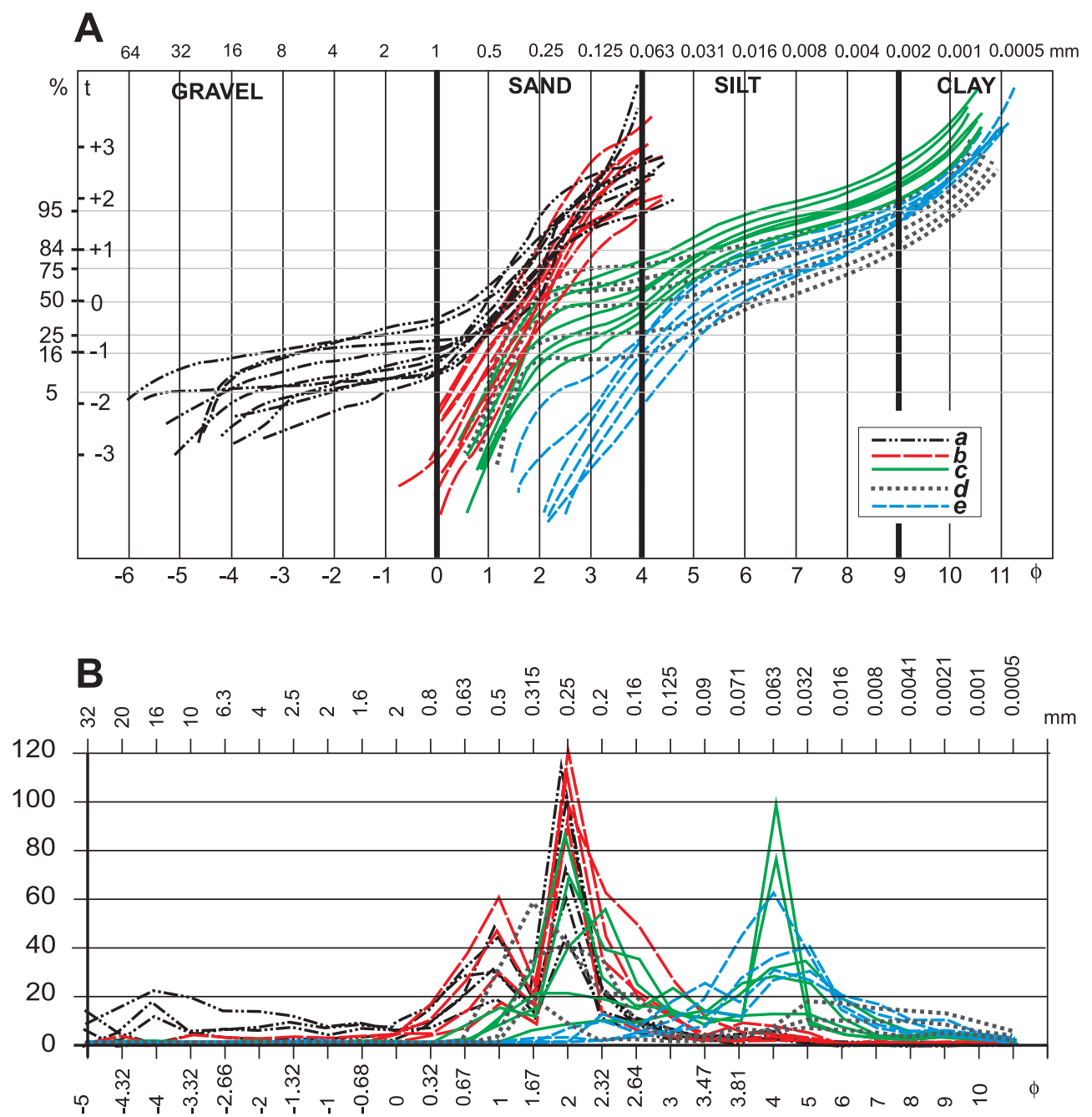

Fig. 4. Comparison of the cumulative and frequency curves for five fluvial facies in the Belnianka River valley: $a=$ thalweg; $b=$ channel outside the thalweg; $c, d=$ overbank current facies; $\mathrm{e}=$ overbank-pool facies

A: Comparison of the cumulative curves; B: Comparison of the frequency curves. 


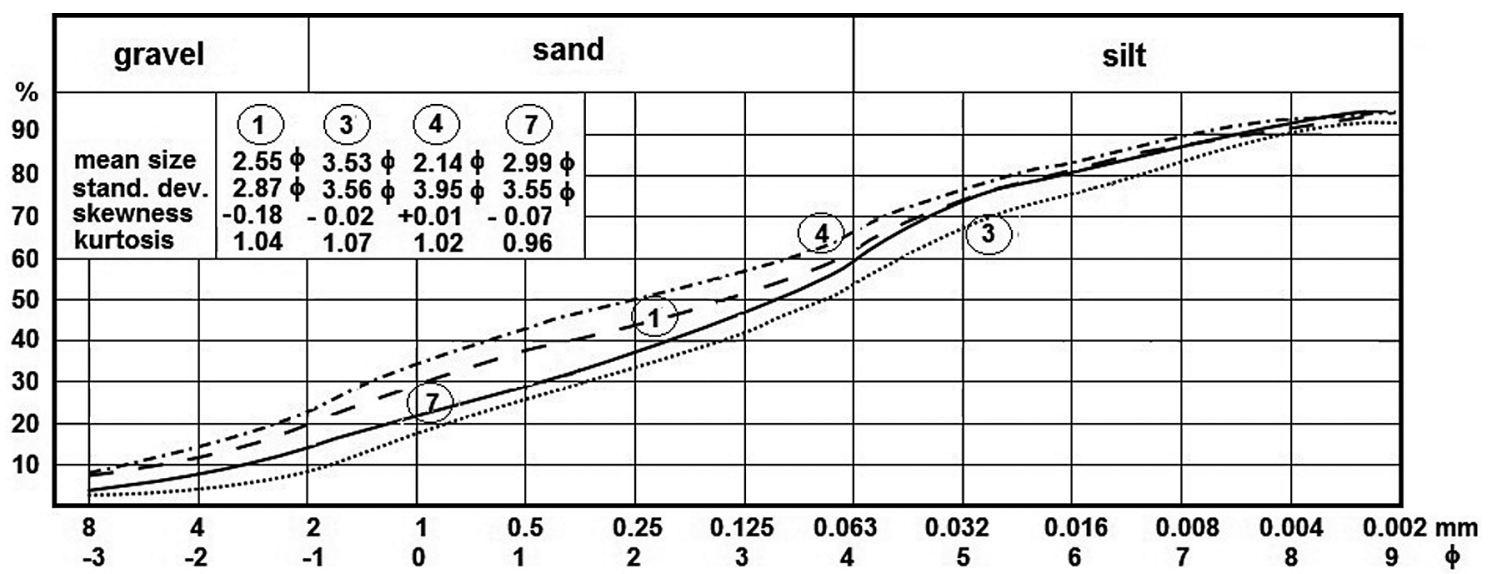

Fig. 5. Cumulative curves for some tills (deposited since Little Ice Age, Iceland) (modified after Krüger, 1994).

section (Fig. 1, segment B?), a certain analogy to Visher's segment B can be seen (sediment transported in suspension), but the steep section at the curve's end (dotted line) represents material with a different history.

\subsubsection{The third group of cumulative curves}

The third, transitional, group of curves (Fig. 1 , graph 1/2) has an inclination of segment A of approx. $45^{\circ}$ (Fig. 3A). This group of cumulative curves comprises sediments which were formed by a relatively short-lived depositional process or in an environment with a higher energy than the first group (Fig. 1, graph 1), but also comprises deposits resulting from various overlapping processes. The curves in this group thus may represent a variety of depositional environments. This group of cumulative curves is also characteristic of run-off sediments, the transport of which could have been initiated by the splashes of raindrops.

The deposits built by material deriving from a proximal floodplain (i.e. close to the river channel) show a similar regularity (Gheith, 2000). The marine coastal environment adjacent to the beach, which is characterised by considerable wave and current dynamics, is built by deposits for which the curves can be classified as belonging to the transitional group (Fig. 1, graph 1/2).

\subsubsection{Conclusions as to the groups of cumulative curves}

As mentioned above, the group of cumulative curves that resemble each other in shape, though differing as to their position on the diagram, are characteristic of deposits composed of grains appearing in various size intervals (Fig. 4A, B). For instance glacial deposits (pebble/gravel/sand/clay mixtures) may exhibit a course of cumulative curves resembling that of flood deposits (sand/silt/clay). This may result from differences in the density of the transporting medium (e.g. fluvial vs. glacial or fluvial vs. aeolian) or different current dynamics (e.g. various facies of fluvial deposits).

\subsection{Frequency curves}

The grain-size distribution of a deposit may also be presented in a frequency curve (Folk, 1971; Besler, 1996; Mycielska-Dowgiałło, 2007) since such curves provide a clear illustration of the relative proportion of grains of the various grain-size fractions. Together with cumulative curves they increase the possibility to interpret the genesis of a deposit and the transport/deposition dynamics.

\subsubsection{Comparison with source material}

A comparison of the frequency curves of dune deposits and of deposits in the same area that form the parent material for the dunes (Fig. 6) illustrates their relationship (MycielskaDowgiałło, 2007) and the capabilities of the aeolian process. It shows that the dunes became enriched with relatively coarse grains because of selective removal of the grains from substratum (cf. Folk, 1971). A similar relationship be- 


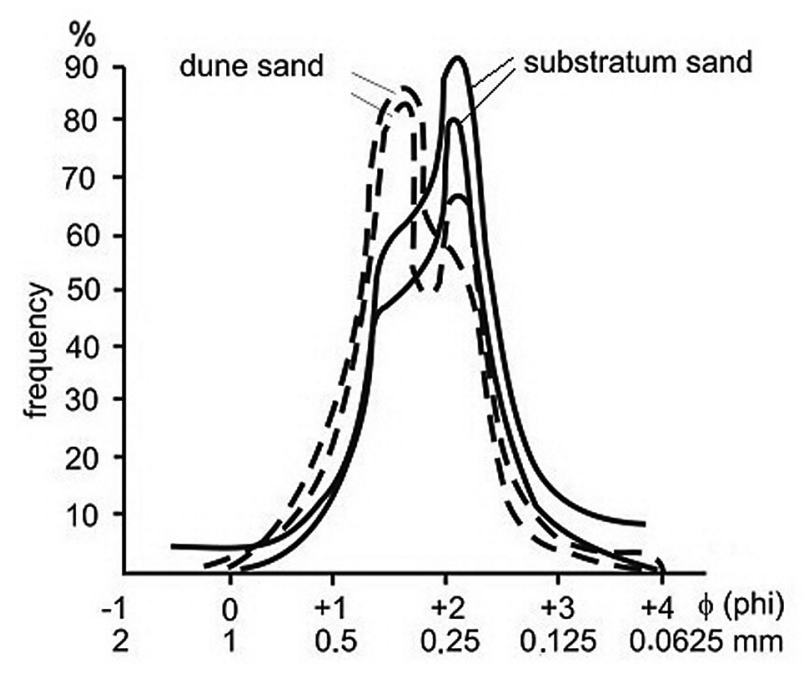

Fig. 6. Relationship of frequency curves for dune sand and the dune's substratum (fluvial sand) in Jeziórko, Sandomierz Basin (Mycielska-Dowgiałło, 2007).

tween source deposits and marine coastal deposits can be found in frequency curves, which had also been noted by Flemming (1988).

\subsubsection{Differentiation between facies}

Frequency curves can also be used to distinguish between different facies (LudwikowskaKędzia, 2000; Szmańda, 2002). In the Belnianka River valley (Holy Cross Mountains, central Poland), for instance, five samples from four fluvial facies (Figs. 3, 4) may be distinguished. These facies show different courses of both the cumulative and the frequency curves (Figs. $3 \mathrm{~A}, \mathrm{~B}, 4)$. The differences between the cumulative curves result from the fraction intervals which they fall into, but they may be similar in shape.

Facies $a$ refers to those channel sediments that are transported through rolling and dragging, and by saltation. Part of the $0.2-0.3 \mathrm{~mm}$ grains (which is a well sorted portion) represents the transport by saltation. This is shown by the inclination of segment $A$ of the cumulative curves (approx. $45^{\circ}$ ) (compare Fig. 1) and by the high peak position in the frequency curves (approx. 110). The spreading in the grain size indicates that the particles accumulated in the part of the river channel with the highest cur- rent velocity (thalweg). All cumulative curves of facies $a$ are contained within the intermediary group (Fig. 1, graph $1 / 2$ ).

Facies $b$ comprises deposits the curves of which show a prevailing saltation segment A (compare Fig. 1) of a somewhat better sorting. This is shown by a steeper inclination of segment A of the cumulative curves (approx. $50^{\circ}-60^{\circ}$ ) and a high peak (approx. 120) in the frequency curves. Contrary to facies $a$, these deposits fall into the first group (Fig. 1, graph 1). The spreadoffing in their grain size points to accumulation in the channel, mainly by saltation.

\subsection{Comparison of cumulative and frequency curves}

The deposits represented by the cumulative and frequency curves in diagrams $c$ and $d$ of Figures 3, 4 are characterised by a most extended segment $B$, representing suspension transport, which adjoins the steep segment (compare Fig. 1, segment A?). The shift of the cumulative curves towards a smaller grain size than that of the channel deposits ( $a$ and $b$ ), as well as the occurrence of the steep segment of the curve (comprising grains within the upper competence limit of a given transport medium) possibly indicates rapid accumulation during a waning flood in overbank areas. This is particularly clear on diagram $d$ (Fig. 3A) and resembles graph 2 in Figure 1 (continuous and dotted lines). The bimodal course and the low peaks of the frequency curves point to poor sorting of particles in both saltation and suspension.

Characteristic of the deposits of the overbank-pool facies $(e)$ is very poor sorting; their frequency curves is mostly monomodal and indicates smaller grains than in the overbank current facies $(d)$.

Figure 4 presents a set of cumulative curves of the various facies of the Belnianka River valley. Despite their similar shapes, the cumulative curves differ in their range of grain sizes. 


\section{Comparison of the textural} parameters and their significance for facies interpretation

If samples from various facies are analysed, their grain-size distributions may be described by textural parameters calculated from cumulative curves. The parameters proposed by Folk \& Ward (1957) are most frequently applied. The relationship between the mean grain size $\left(M_{z}\right)$ and the standard deviation, i.e. the sorting parameter $\left(\sigma_{\mathrm{I}}\right)$, is a good tool for reconstructing the transport and depositional processes. Studies of various types of aeolian sediments in the Taklamakan Desert (analysing frequency curves and comparing granulometric indicators), for instance, have enabled to draw conclusions relating to process duration, migration of aeolian forms and transport types (Besler, 1996).

\subsection{Co-ordinate system}

A co-ordinate system (Fig. 7) has been developed that shows tendencies in sorting of various grain sizes of the material transported in different environments (Mycielska-Dowgiałło, 2007), where the symbols $\mathrm{Mz}$ and $\sigma_{\mathrm{I}}$ represent respectively the mean grain diameter and sorting degree after Folk \& Ward (1957).

\subsubsection{The first co-ordinate system}

The first co-ordinate system (Fig. 7 line 1) is found most frequently where the increase of the mean grain size $(\mathrm{Mz})$ is accompanied by a diminishing sorting $\left(\sigma_{\mathrm{I}}\right)$. This system is typical of depositional environments with high variability of transport energy. Phases of lowenergy transport (e.g. by water or air), during which the sorting of the deposited material takes place, alternate with brief phases of higher-energy transport which - when rapidly

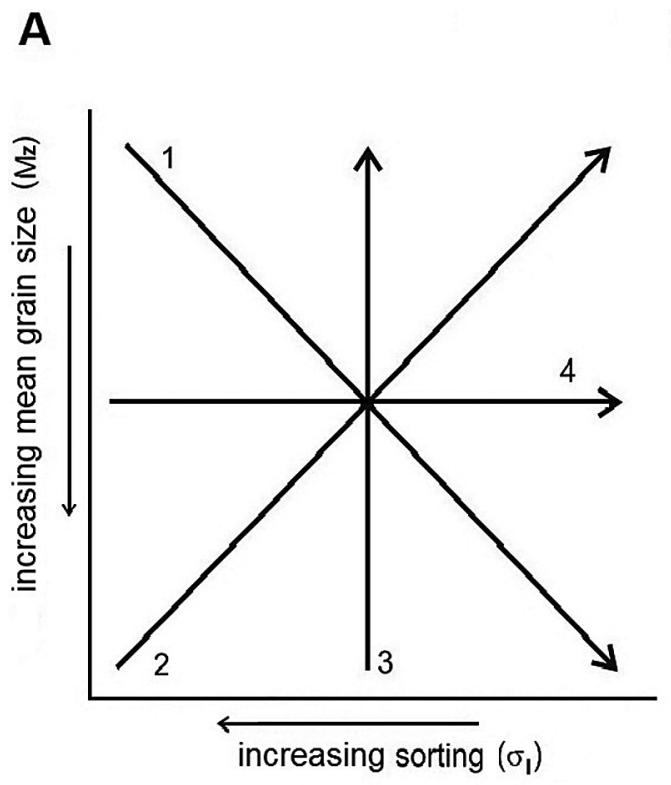

B

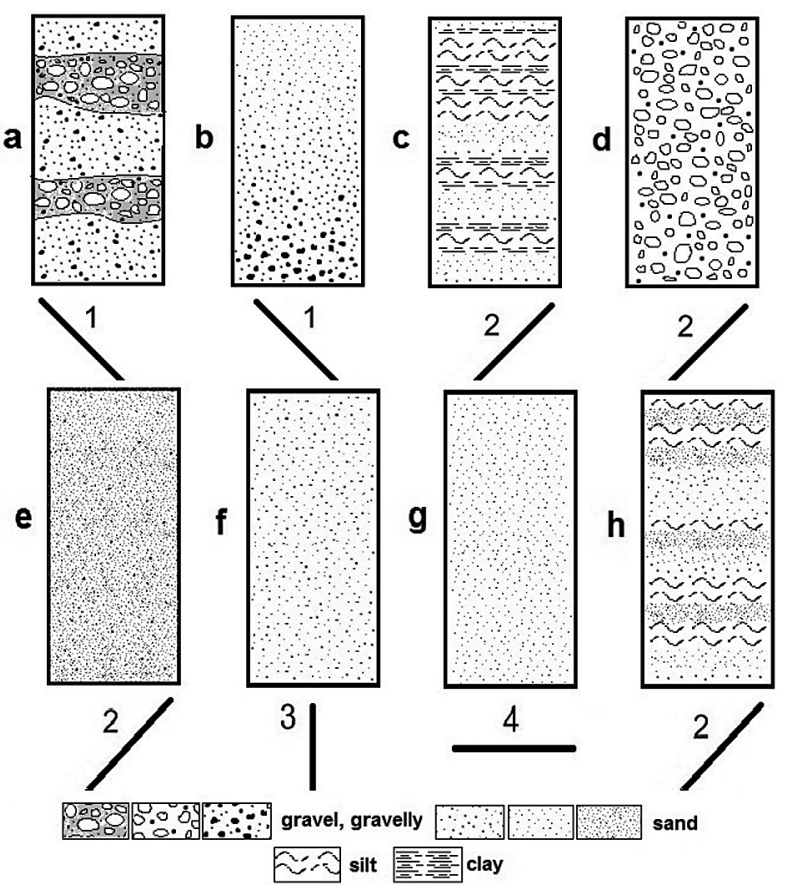

Fig. 7. Principles of the co-ordinate system.

A: Basic regression lines, for genetically homogeneous deposits, derived from the relationship between $\sigma_{\mathrm{I}}$ (sorting) and $\mathrm{Mz}$ (mean grain size). 1 = channel deposits; 2 = overbank deposits, aeolian deposits of hot deserts, wash-out deposits, fluvial channel lag; 3 = aeolian deposits of the moderate climate zone, overbank-pool deposits; $4=$ slope sediments formed by splashing of rain drops; B: Some characteristic facies: a = braided-river and subglacial-channel deposits; $\mathrm{b}=$ channel infilling of meandering rivers; $\mathrm{c}=$ overbank deposits; $\mathrm{d}=$ lag deposits; $\mathrm{e}=$ dune deposits of recent deserts; $\mathrm{f}=$ dune deposits from central Poland; $\mathrm{g}=$ slope deposits related to raindrop splashes; $\mathrm{h}=$ alluvial fan deposits (modified after Mycielska-Dowgiałło, 2007). 
declining - result in the accumulation of particular coarse-grained material forming poorly-sorted deposits. This occurs most frequently in fluvial (and thus also in fluvioglacial) channels (Harasimiuk, 1991; Niedziałkowska, 1991; Kothyari, 1995; Ludwikowska-Kędzia, 2000).

The first co-ordinate system (Fig. 7A) is rarely found in aeolian deposits. It is characteristic of areas with considerable wind dynamics (Sarre \& Chancey, 1990; Besler, 1996; Wang et al., 2003). It has also been referred to sediments derived from wash-out on slopes (Twardy, 2004). It was also identified in very fine-grained deposits, in the 4-6 $\Phi$ interval of floodplain deposits in the Wisłoka River (CzyżowskaWiśniewska, 2003). The first system was also identified by Kordowski (2003) within very fine-grained (4-8 $\Phi)$ deposits in an overbank area of the lower Vistula River valley, where ribbons of sandy deposits occur. The interpretation of the transport and depositional history of the sediments that are represented by this cluster of points within the silt fraction is not completely clear (in general flood deposits are depicted in the second system).

\subsubsection{The second co-ordinate system}

The second co-ordinate system (Fig. 7, line $2)$, wherein the sorting $\left(\sigma_{\mathrm{I}}\right)$ diminishes parallel with a decreasing mean grain size $(\mathrm{Mz})$, refers to media with prevalent sorting processes within the range of a coarser fraction (sand) and with periodical supply of a poorly-sorted finer fraction (silt) transported in suspension. The accumulation may take place during a rapid decrease in the competence of the transporting medium (e.g. silt deposition after a sand storm, or accumulation from suspension during a waning flood). This is particularly characteristic of aeolian deposits in hot deserts (Mycielska-Dowgiałło, 2007) and of floodplain deposits (Starkel et al., 1982; Florek et al., 1990; Rizzetto et al., 1998; Ludwikowska-Kędzia, 2000; Szmańda, 2002, 2007).

The course of the regression lines is presented here together with sedimentary logs of some facies (Fig. 7B). It should be stressed that the proper classification of deposits with a similar course of the regression lines (e.g. Fig.
$7 \mathrm{~B}, \mathrm{a}, \mathrm{b})$ requires analysis of the structures in these deposits.

The lag deposits (Fig. 7B, d) consist often of washed-out coarse fluvioglacial deposits at river bottoms.

The second system has also been found in slope wash-out deposits without sorting, and where accumulation is very rapid (Smolska, 2003; Twardy, 2004). It can also be found in channel lags where the coarse-grained fraction is best sorted (Ostrowska et al., 2004). Based on the relationship between mean grain-size and standard deviation, channel deposits (the first system) can easily be distinguished from fluvial lag deposits (the second system) (Fig. 8A). The distinction should be based on the range of the mean grain size; as a rule the fluvial lag deposits are coarser than the channel infilling. Thus, the range of the grain size should also be considered.

\subsubsection{The third co-ordinate system}

The third system (Fig. 7, line 3) with a constant degree of sorting rate $\left(\sigma_{\mathrm{I}}\right)$ and a variable mean grain size $(\mathrm{Mz})$, seems typical of less dynamic environments characterised by small variations in the energy of the transport medium, as well as by low-density transport media, e.g. air. Accumulation through saltation or suspension prevails. When comparing the results of the third system, aeolian deposits are inclined to be better sorted than overbankpool deposits (Fig. 8B). This type of system is characteristic of sandy sediments which form active parabolic dunes (Sarre \& Chancey, 1990; Ruz \& Allard, 1995; Rizzetto et al., 1998), and it is also found in the majority of Polish fossil dunes (Mycielska-Dowgiałło,2007). The third system also includes deposits accumulated in stagnant water, e.g. in oxbow lakes.

\subsubsection{The fourth co-ordinate system}

Recently, indications were found that the fourth system is characteristic of wash-out deposits on slopes. In this system, the sediment sorting $\left(\sigma_{\mathrm{I}}\right)$ varies despite a constant mean grain size $(\mathrm{Mz})$. This system is linked with a slope system where the rain splashing is the dominant process (Fig. 7 line 4). 

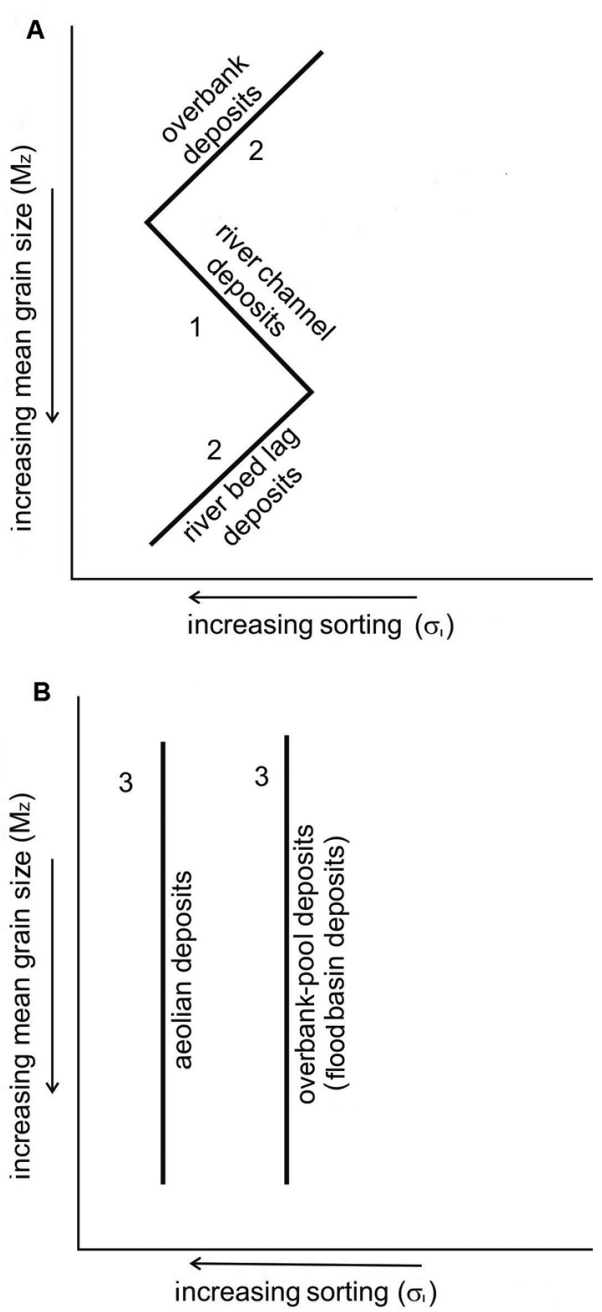

Fig. 8. The co-ordinate systems.

A: The first and second system (from Fig. 7) presented in a diagram relating the mean grain size $\left(M_{z}\right)$ and the sorting rate $\left(\sigma_{\mathrm{I}}\right)$. The trends change in accordance with grain-size intervals as well as sedimentary subenvironments; B: The third system (from Fig. 7) with aeolian and overbank-pool facies (from MycielskaDowgiałło, 2007).

\subsubsection{A case history from central Mongolia}

The grain-size distribution for dunes and regs in central Mongolia (Potocki \& Angiel, 2004) points to three different tendencies: for reg deposits (the second system; Fig. 7, line 2), for deposits at dune bases (the first system; Fig. 7, line 1), and for deposits from dune ridges (the third system; Fig. 7, line 3). It seems that various dynamics of deflation, transport and accumulation of sediments are expressed by these three systems.

The deposits from the dune base, where the highest dynamics of spin currents prevails, concentrate within the first system, whereas the third system is formed by deposits from dune ridges where the sorting process prevails, irrespective of the grain size.

Within the reg area, the coarsest grains are selected by wind deflation (resulting in good sorting), as well as additional settling of poorly-sorted fine-grained sediment transported in suspension. This process has also been described for the Negev Desert by Goossens (1995).

\subsection{Relationships between granulometric parameters}

For the interpretation of the transport and depositional history of fluvial deposits, the relationships of several granulometric parameters must be taken into consideration. This regards the: mean grain size vs. standard deviation $\left(\mathrm{Mz}\right.$ and $\left.\sigma_{\mathrm{I}}\right)$, the skewness vs. the mean grain size $\left(\mathrm{Sk}_{\mathrm{I}}\right.$ and $\left.\mathrm{Mz}\right)$, and the standard deviation vs. the skewness $\left(\sigma_{\mathrm{I}}\right.$ and $\left.S \mathrm{~K}_{\mathrm{I}}\right)$. These relationships are presented in the diagrams as fields of points (Fig. 9).

Worth noting is the overlapping of two fields of points representing different facies (river channel deposits and overbank deposits) (Fig. 9A). The common part of the two fields corresponds to the best sorted grain-size (approx. $2 \Phi=0.25 \mathrm{~mm}$ ). The boundary between the two facies in Fig. 9C is, similarly, situated in the zone of the best sorting and the zero value of skewness. The plot, obtained for channel and overbank deposits of the same river, forms a parabolic diagram. Channel deposits concentrate on the left-hand side of the parabola, whereas overbank ones occur on the righthand side (cf. Ludwikowska-Kędzia, 2000).

The relationship between skewness $\left(\mathrm{Sk}_{\mathrm{I}}\right)$ and mean grain size $(\mathrm{Mz})$ shows a system of several 'waves' (Fig. 9B). The lowermost wave within the negative skewness values represents channel deposits. The next wave, already in the range of positive skewness values and finer grains, represents overbank deposits. The third wave, in the range of skewness values lower than those of the preceding wave and with a still finer grain size, represents stagnant- 

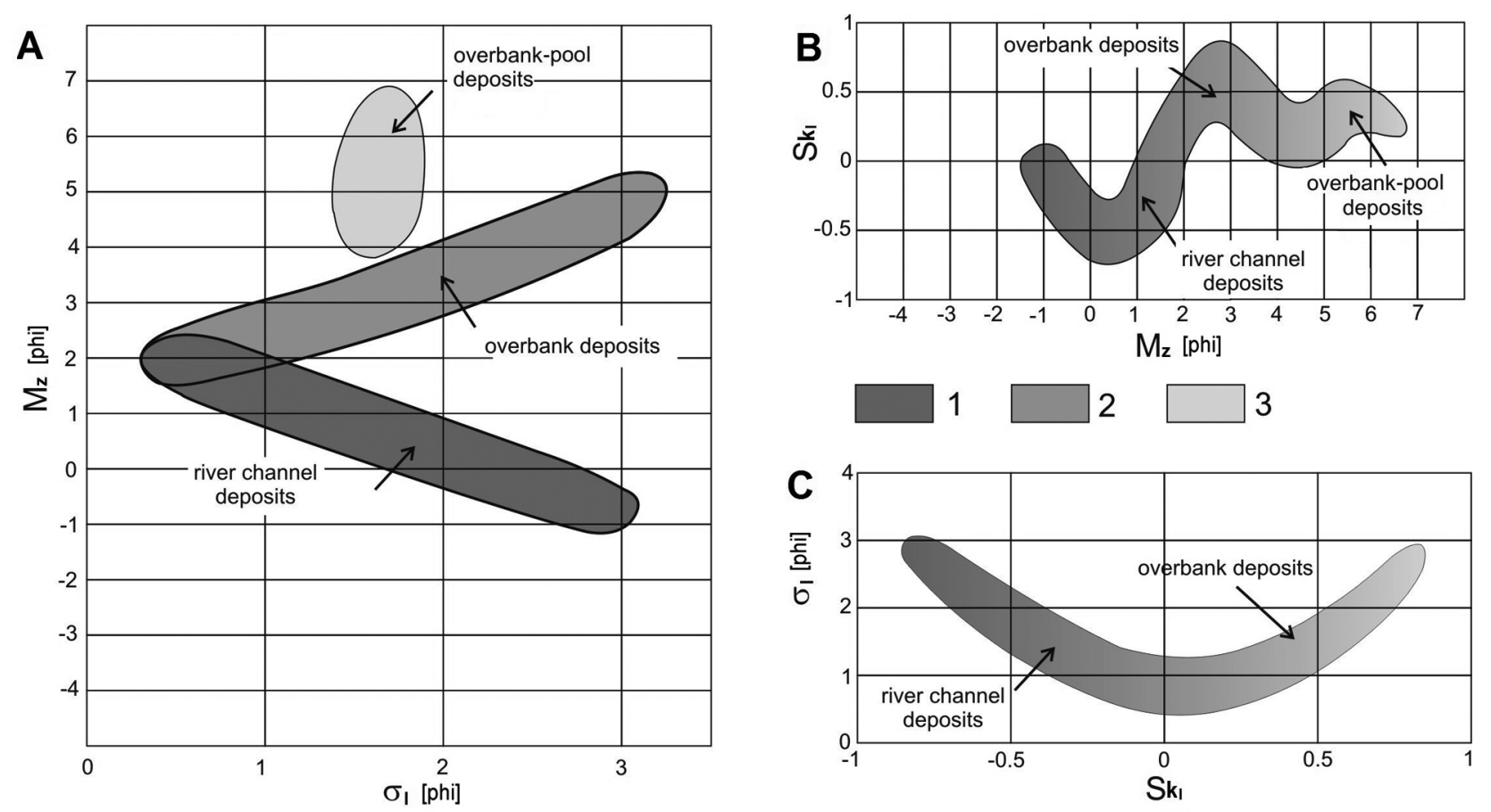

Fig. 9. Relationships of Folk \& Ward textural parameters (modified from Ludwikowska-Kędzia, 2000; MycielskaDowgiałło, 2007).

A: Mean grain diameter $(\mathrm{Mz})$ vs. standard deviation $\left(\sigma_{\mathrm{I}}\right)$; B: Skewness $\left(\mathrm{Sk}_{\mathrm{I}}\right)$ vs. mean grain diameter $(\mathrm{Mz})$; C: Standard deviation $\left(\sigma_{\mathrm{I}}\right)$ vs. skewness $\left(\mathrm{Sk}_{\mathrm{I}}\right)$.

water deposits. A similar system of two (second and third) waves for overbank deposits has been presented by Szmańda (2002) for the Drwęca River valley.

A study by Kordowski (2003) concerning overbank deposits in the lower Vistula River valley makes it possible to specify precisely their location in the range of the wave-shaped diagram. Just like in the presented diagram, the lower left-hand segment of the lowest wave represents channel deposits and the overbank sandy deposits. The second wave mainly concentrates on deposits accumulated at the river side of the natural levee, passing downwards into overbank-pool deposits left after flooding. The third wave refers to deposits filling the oxbow lakes, swamps and lacustrine depressions.

\section{Application of the C-M diagram to palaeoenvironmental interpretation}

The C-M diagram (Passega, 1957, 1964) is another method for presenting the results ob- tained from grain-size analyses, wherein the values of the first percentile $(C)$ are plotted against the median (M)(probability scale). The $C$ and $M$ values may be presented in $\Phi$ units and/or in millimetres. Thus far, the so-called Passega C-M diagram has been applied in particular to the study of fluvial and coastal deposits, because both consist of different lithofacies, which can be 'translated' into depositional subenvironments with the help of the diagram. Different transport and depositional histories can thus be distinguished (LudwikowskaKędzia, 2000; Szmańda, 2002).

According to Passega (1957, 1964) and Passega \& Byramjee, (1969) the first percentile refers to the grain size that is representative of the maximum competence of the transporting medium. Based on the analysis of river and marine coastal deposits, Passega \& Byramjee (1969) distinguished three basic limits, viz. $\mathrm{Cr}$ ( $\mathrm{C}$ - rolling), $\mathrm{Cu}$ (C - uniform suspension) and Cs (C - graded suspension) (Fig. 10). The $\mathrm{Cr}$ forms the lower size limit of grains transported through rolling (with a contribution of suspension); the Cs characterises the maximum diameter of grains transported in 'graded suspen- 


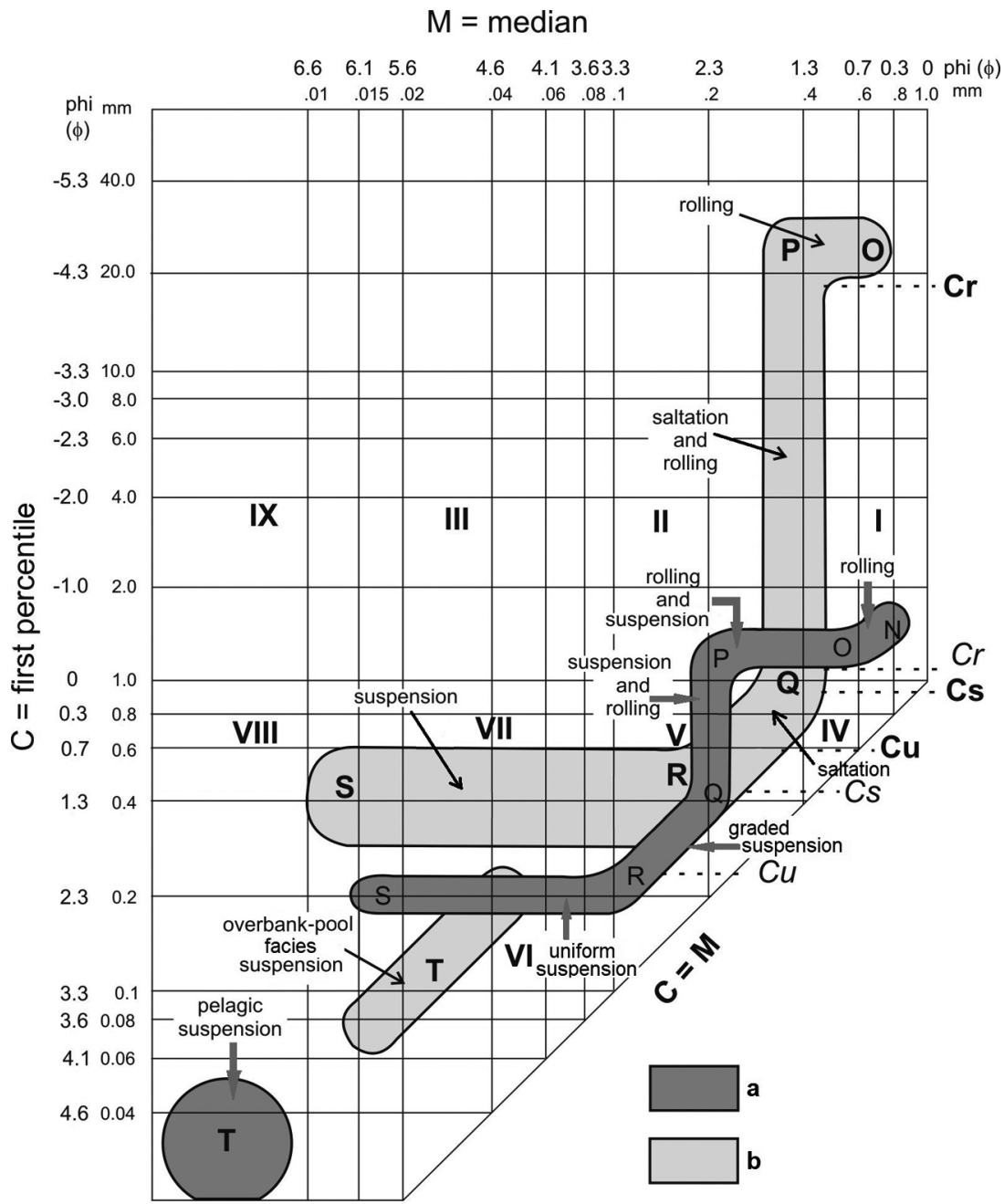

Fig. 10. C-M diagram. a: according to Passega (1964) and Passega \& Byramjee (1969); b: according to Ludwikowska-Kędzia (2000) for fluvial deposits in the Belnianka River valley. The letter symbols are explained in the text. Location of $\mathrm{Cr}, \mathrm{Cs}$, and $\mathrm{Cu}$ symbols following Passega (1964) in italics; following Passega \& Byramjee (1969) in bold (modified after Ludwikowska-Kędzia, 2000; Mycielska-Dowgiałło, 2007). sion', i.e. mainly through saltation; and $\mathrm{Cu}$ is the limit for the maximum size of grains transported in homogeneous suspension, i.e. in the upper part of the water column.

On the diagram (Fig. 10), characteristic sections indicative of different transport and sedimentation modes can be distinguished (Passega \& Byramjee 1969). They include transport in a homogeneous suspension (SR), transport in 'graded suspension', mainly through saltation (RQ), transport through suspension with some rolling (QP), transport through rolling with a contribution of suspension (PO), transport exclusively through rolling $(\mathrm{N})$, and settling from suspension in stagnant water $(\mathrm{T})$.

For fluvial deposits in the Belnianka River valley (in the Holy Cross Mountains area) a Passega \& Byramjee (1969) diagram (Fig. $10 \mathrm{~b}$ ), cumulative curves of various facies (e.g. Fig. 3A) and a diagram of the relationship be- tween the values of the mean grain size $(\mathrm{Mz})$ and standard deviation $\left(\sigma_{\mathrm{T}}\right)$ have been prepared (Fig. 9A). The boundary between SR and RQ (Fig. 10b) corresponds to the place where two fields of points representing different subenvironments (river channel and overbank) overlap each other (Fig. 9A).

While analysing coastal deposits, Passega (1964) noted that the Cs limit becomes lower with increasing depth of the marine basin. This is due to the turbulence and wave activity which decrease towards deeper parts of marine basins. Similarly, when comparing fluvial deposits in rivers of various gradients and various current dynamics, an upward shift of the $\mathrm{Cu}$ and $\mathrm{Cs}$ limit (towards higher $\mathrm{C}$ values) has been noted.

The scope of the aforementioned study (Passega, 1964) has been further extended by Royse $(1968,1970)$, who analysed deposits in 
rivers with known conditions of the current, load, and concentration of clastic material. Sedimentological studies in Poland have also been conducted on deposits of rivers with different gradients and dynamics, and have extended the scope of interpretative possibilities for the Passega diagram (Ludwikowska-Kędzia, 2000; Szmańda, 2002; Ostrowska et al., 2003).

These studies have shown that data on C-M diagrams (as in Fig. 10b) show a shift towards higher C values than the original Passega (1964) diagram (Fig. 10a). This phenomenon is directly proportional to the gradient and current dynamics of the river. This shift is particularly well visible as for the course of the $\mathrm{Cr}$ limit at high $\mathrm{C}$ values.

The Passega (1964) diagram may thus still be useful for the investigation of fluvial deposits, although it was elaborated originally for the marine environment.

\section{Conclusions}

We conclude that the sedimentary environment, the dynamics of the transport and depositional process, the density of the transport medium, the duration of the process and several other data can be reconstructed on the basis of granulometric characteristics. The methods presented here can be used for the purpose as follows:

(1) cumulative curves at a probability scale in combination with frequency curves provide through their shape (inclination, spreading of grain sizes) information on the depositional environment (and its various subenvironments), transport mode (suspension, saltation or rolling) and the density and dynamics of the transporting medium;

(2) comparison of frequency curves for a deposit and for its parent material may show both a similar grain-size distribution and the tendency to decrease this similarity during transport;

(3) the four regression lines for clusters of points representing the relationship between sorting $\left(\sigma_{\mathrm{I}}\right)$ and mean grain size $(\mathrm{Mz})$ may suggest the sedimentary environment and the dynamics of transport and accu- mulation, as well as - in the case of aeolian deposits - the duration of the process, but it is advised to confirm the results by comparing them with the course of the cumulative curves;

(4) the relationships between the various Folk \& Ward (1957) parameters may be a good tool for analyzing the sedimentary environment diagnosis, as indicated by the case history in which - based on comparison of the relationships of three indices $\left(\mathrm{Mz}, \sigma_{I^{\prime}}\right.$ $\left.\mathrm{Sk}_{\mathrm{I}}\right)$ - the subenvironments of fluvial deposits of the upland Belnianka River in the Holy Cross Mountains were distinguished.

\section{References}

Benn, D.I. \& Evans, D.J.A., 1998. Glaciers and glaciation. Arnold, London, 734 pp.

Besler, H., 1996. Granulometrische Sandtypen im Wüstenvergleich (Häufigkeitsverteilungen als Informationsträger). Zeitschrift für Geomorpholgie N.F., 40, 23-46.

Cichosz-Kostecka, A., Mycielska-Dowgiałło, E. \& Manikowska, B., 1991. Late Glacial aeolian processes in the light of sediment analysis from Kamion profile near Wyszogród. Zeitschrift für Geomorpholgie N.F. Suppl. Bd. 90, 45-50.

Czyżowska-Wiśniewska, E., 2003. Powodzie i wspótczesna sedymentacja osadów powodziowych w dolinie Wistoki [Floods and contemporary flood deposition in the Wisłoka River valley]. Ph.D. thesis Polish Academy of Sciences, Warszawa, 12 pp.

Elsner, H., 1992. Granulometry and mineralogy of some northeastern Florida places: a consequence of heavy mineral concentration in nearshore bars. Sedimentary Geology 76, 233-255.

Flemming, B.W., 1988. Process and pattern of sediment mixing in a microtidal coastal lagoon along the west coast of South Africa. [In:] P.L. de Boer, A. van Gelder \& S.D. Nio (Eds): Tide-influenced sedimentary environments and facies. D. Reidel, Dordrecht, 275-288.

Flemming, B.W., 2007. The influence of grain-size analysis methods and sediment mixing on curve shapes and textural parameters: implications for sediment trend analysis. Sedimentary Geology 202, 425-435.

Florek, W., Mycielska-Dowgiałło, E. \& Starkel, L., 1990. Lithology and facies of fluvial deposits. [In:] L. Starkel (Ed): Evolution of the Vistula River valley during the last 15000 years, Part III. Geographical Studies Special Issue 5 (Ossolineum, Wrocław), 111-126.

Folk, R.L., 1971. Longitudinal dunes of the northwestern edge of the Simpson desert, Northern Territory, Australia, 1. Sedimentology 16, 5-54.

Folk, R.L. \& Ward W., 1957. Brazos River bar: A study in the significance of grain size parameters. Journal of Sedimentary Petrology 27, 3-26. 
Friedman, G.M. \& Sanders, J.E., 1978. Principles of sedimentology. Wiley, New York, 792 pp.

Friedman, G.M., Sanders, J.E. \& Kopaska-Merkel, D.C., 1992. Principles of sedimentary deposits, stratigraphy and sedimentology. Macmillan Publ. Comp., New York, 717 pp.

Garde, R.J., 1972. Bed material characteristics of alluvial streams. Journal of Sedimentary Petrology 7, 127-135.

Gheith, A.M., 2000. Sedimentary reflections of the coastal processes on the shore zone sediments along the eastern Red Sea coast, Saudi Arabia. Zeitschrift für Geomorpholgie N.F. 44, 449-468.

Goossens, D., 1995. Field experiments of aeolian dust accumulation on rock fragment substrata. Sedimentology 42, 391-402.

Harasimiuk, M., 1991. Vistulian glacial cycle of the fluvial processes development in the valley of the middle Wieprz River (SE Poland). Annales UMCS 46, 81-109.

Hartmann, D., \& Flemming, B. (Eds), 2007. From particle size to sediment dynamics. Sedimentary Geology 202, 333-580.

Izmaiłow, B., 2001. Typy wydm śródlądowych w świetle badań struktury i tekstury ich osadów (na przykładzie dorzecza górnej Wisty) [Types of inland dunes in the light of structural and textural analysis of aeolian deposits (with the upper Vistula catchment area as an example)] Jagiellonian University Press, Krakow 282 pp.

Kordowski, J., 2003. Struktury wewnętrzne i uziarnienie osadów pozakorytowych doliny dolnej Wisły w Kotlinie Toruńskiej i Basenie Unisławskim [Structures and granulometry of overbank deposits of the lower Vistula River valley in the Torun and Unisław Basins]. Przeglad Geograficzny 75, 601-621.

Komar, P.D., 1985. The hydraulic interpretation of turbidites from their grain size and sedimentary structures. Sedimentology 32, 395-407.

Kothyari, U.C., 1995. Frequency distribution of river bed materials. Sedimentology 42, 283-291.

Krüger, J., 1994. Glacial processes sediments, landforms and stratigraphy in the terminus region of Myrdalsjökull, Iceland. Folia Geographica Danica 21, 233 pp.

Ludwikowska-Kędzia, M., 2000. Ewolucja środkowego odcinka doliny rzeki Belnianki w późnym glacjale i holocenie [Evolution of the middle segment of the Belnianka River valley in the Late Glacial and Holocene]. Dialog Press, Warsaw, 180 pp.

Mycielska-Dowgiałło, E., (Ed), 1988. Geneza osadów i gleb $w$ świetle badań $w$ mikroskopie elektronowym [Genesis of deposits and soils on the basis of SEM analysis]. Warsaw University Press, 180 pp.

Mycielska-Dowgiałło, E., 1992. Desertification on the basis of sedimentological features of dune deposits. Geographica Polonica 60, 181-195.

Mycielska-Dowgiałło, E., 1993. Estimates of Late Glacial and Holocene aeolian activity in Belgium, Poland and Sweden. Boreas 22, 165-170.

Mycielska-Dowgiałło, E. (Ed), 2001. Eolizacja osadów jako wskaźnik stratygraficzny czwartorzędu [Aeolization of sediments as an indicator of Quaternary stratigraphy]. Warszawa, $141 \mathrm{pp}$.
Mycielska-Dowgiałło, E., 2007. Metody badań cech teksturalnych osadów klastycznych i wartość interpretacyjna wyników [Research methods for textural features of clastic deposits and the significance of interpretational results]. [In:] E. Mycielska-Dowgiałło \& J. Rutkowski (Eds): Badania cech teksturalnych osadów czwartorzedowych i wybrane metody oznaczania ich wieku [Research into the textural features of Quaternary sediments and some dating methods]. The Family Alliance School of Higher Education Press, Warsaw, 95-180.

Mycielska-Dowgiałło, E., Pękalska, A. \& Woronko, B., 1995. The evolution of a marginal form and of kames in the region of Bielsk Podlaski. Sedimentological analysis of deposits. Quaestiones Geographicae 4, 215224.

Mycielska-Dowgiałło, E. \& Woronko B., 2004. The degree of aeolization of Quaternary deposits in Poland as a tool for stratigraphic interpretation. Sedimentary Geology 168, 149-163.

Niedziałkowska, E., 1991. The textural diversity of upper Quaternary fluvial deposits in the Carpathian Foreland. Geographica Studia Special Issue 6, 119-146.

Ostrowska, A., Oświecimska-Piasko, Z. \& Smolska E., 2003. Cechy sedymentologiczne różnowiekowych osadów korytowych na przykładzie doliny górnej Czarnej Hańczy (Pojezierze Suwalskie) [Sedimentological indices of channel-facies deposits with the upper Czarna Hańcza River valley (Suwałki Lakeland) as an example]. [In:] E. Smolska \& P. Szwarczewski (Eds): Cechy teksturalne osadów stokowych i fluwialnych [Textural indices of slope and fluvial deposits]. Prace i Studia Geograficzne (Warszawa) 33, 59-70.

Passega, R., 1957. Texture as characteristic of clastic deposition. American Association of Petroleum Geologists Bulletin 41, 1952-1984.

Passega, R., 1964. Grain size representation by CM patterns as a geological tool. Journal of Sedimentary Petrology 34, 830-847.

Passega, R. \& Byramjee, R., 1969. Grain-size image of clastic deposits. Sedimentology 13, 233-252.

Potocki M., \& Angiel P., 2004. Change of grain size parameters of sediments as a result of wind activity. Barchans Jarangiyn els in Gobi, Mongolia. Misceallanea Geographica 11, 81-91.

Racinowski, R., Szczypek, T., \& Wach J., 2001. Prezentacja i interpretacja wyników badań uziarnienia osadów czwartorzędowych [Presentation and interpretation of the grainsize distribution of Quaternary sediments]. University of Silesia Press, Katowice 146 pp.

Rizzetto, F., Mycielska-Dowgiałło, E. \& Castiglioni, G.B., 1998. Some aeolian features in the Po plain near Este (North Italy). Geografia Fisica e Dinamica Quaternaria 21, 245-253.

Royse C.F., 1968. Recognition of fluvial environments by particle-size characteristics. Journal of Sedimentary Petrology 38, 1171-1178.

Royse, C.F., 1970. A sedimentologic analysis of the Tongue River - Sentinel Butte Interval (Paleocene) of the Williston Basin, western North Dakota. Sedimentary Geology 4, 19-80. 
Ruz, M.H. \& Allard, M., 1995. Sedimentary structures of cold-climatic dunes. Eastern Hudson Bay, Canada. Sedimentology 42, 725-734.

Sarre, R.D. \& Chancey, C.C., 1990. Size segregation during aeolian saltation and sand dunes. Sedimentology $37,357-365$.

Seppälä, M., 2004. Wind as a geomorphic agent in cold climates. Cambridge University Press, 358 pp.

Smolska, E., 2003. Cechy deluwiów na przykładzie osadów stokowych pagórka w okolicy Łopuchowa na Pojezierzu Suwalskim [Wash-off properties: the case of slope deposits on a hill near Łopuchowo (Suwałki Lakeland)]. [In:] E. Smolska \& P. Szwarczewski (Eds): Cechy teksturalne osadów stokowych i fluwialnych [Textural indices of slope and fluvial deposits]. Prace $i$ Studia Geograficzne (Warszawa) 33, 45-57.

Starkel, L., Klimek, K., Mamakowa, K. \& Niedziałkowska, E., 1982. The Wisłoka river valley in the Carpathian Foreland during the Late Glacial and the Holocene. Geographica Studia Special Issue 1, 41-56.

Szmańda, J. B., 2002. Litofacjalny zapis powodzi w wybranych fragmentach równin zalewowych Wisty, Drwęcy i Tążyny [Lithofacies flood record in some fragments of the Vistula, Drwęca and Tążyna River valleys]. Nicolaus Copernicus University (Toruń) $125 \mathrm{pp}$.

Szmańda, J., 2007. Porównanie interpretacji warunków transport osadów na diagramie C/M i analizy krzywych kumulacyjnych aluwiów pozakorytowych Wisły w Toruniu [Grain-transport conditions: an interpretative comparison on the analysis of $\mathrm{C} / \mathrm{M}$ diagrams and cumulative curve diagrams, with the overbank deposits of the Vistula River, Torun, as an example].
[In:] E. Smolska \& D. Giriat (Eds): Rekonstrukcja dynamiki procesów geomorfologicznych - formy rzeźby i osady [Reconstruction of morphological process dynamics - landforms and deposits]. Warszawa, 367-376.

Tanner, W., 1964. Modification of sediment size distributions. Journal of Sedimentary Petrology 34, 156-164.

Twardy, J., 2004. Przebieg holoceńskiej ewolucji stoków doliny Warty na obszarze południowej części kotliny Sieradzkiej w świetle analiz osadów stokowych [Holocene slope evolution of the Warta River valley in the southern part of the Sieradz Basin on the basis of an analysis of the slope deposits]. Acta Geographica Lodziensia 88, 49-84.

Visher, G.S., 1969. Grain size distribution and depositional processes. Journal of Sedimentary Petrology 39, 1074-1106.

Wang, X., Dong, Z., Zhang, J., Qu, J. \& Zhao A., 2003. Grain size characteristics of dune sands in the central Taklimakan Sand Sea. Sedimentary Geology 161, 1-14.

Weltje, G.J. \& Prins, M.A., 2007. Genetically meaningful decomposition of grain-size distributions. Sedimentary Geology 202, 409-424.

Zieliński, P., Fedorowicz, S. \& Zaleski, I., 2009. Sedimentary succession in Berezno in the Volhynia Polesie (Ukraine) as an example of depositional environment changes in the periglacial zone at the turn of the Vistulian and the Holocene. Geologija 51, 99-110.

Manuscript received: 21 March 2011 Revision accepted: 8 December 2011 